\title{
Institutional and Artistic Changes in Estonian Performing Arts with a Case Study of Vaba Lava / Open Space
}

\author{
MADLI PESTI \& \\ KRISTIINA REIDOLV
}

\begin{abstract}
The article gives an insight into the theatre system of Estonia, the development of the system in the turmoil of history and the current situation in the 21st century.

The first part of the article looks back at a period of 30 years: what happened with the Estonian theatre system when it moved from the Soviet occupation period into the Republic of Estonia. We show the developments in the funding system of theatres during the big changes in the socio-economic environment. We give an insight into how theatres are funded nowadays: how the funding of public and private theatres is connected with the quantitative (the number of premieres, performances and visits to the theatre) and qualitative (nominations, awards and artistic tendencies) results.

The second part of the article is a case study. We introduce a new type of performing arts organization in the Nordic and Baltic countries - Vaba Lava (Open Space) in Tallinn, which is funded as a PPP (public private partnership) in cooperation between the private and the public sector. Vaba Lava offers an open platform to all private theatres and companies offering them both a stage for performing as well as support services. The core of the Vaba Lava programme is its International Curated Programme. Performances of the programme are selected by a team of curators who announce an International Open Call. The projects are selected from the applications submitted to the competition. We show how this kind of theatre is adapting to the funding system and what kind of performance strategies and working practices have been developed. We analyse what are the main artistic ideas of the international programme that also gives voice to underprivileged people talking about socially relevant themes.

The general research questions of the article are: how has Estonian theatre developed during the last decades and how it is adapting to the prevailing financial system? What kind of performance strategies and working practices have been developed and how do the economic conditions affect the artistic outcome?
\end{abstract}

\section{KEYWORDS}

Estonian theatre system, financing of theatres, new working methods

ISSN 2002-3898

(C) Madli Pesti \& Kristiina Reidolv and Nordic Theatre Studies

PEER REVIEWED ARTICLE Open access: https://tidsskrift.dk/nts/index

Published with support from Nordic Board for Periodicals in the Humanities and

Social Sciences (NOP-HS) 


\section{Institutional and Artistic Changes in Estonian Performing Arts with a Case Study of Vaba Lava / Open Space}

\section{INTRODUCTION}

The paper gives an overview of the Estonian theatre system focusing on the period of re-independence - from 1991 to the present. It indicates the principles of financing the performing arts institutions and aims at clarifying how financing can influence artistic decisions. The paper asks how institutional changes, such as the opening up to foreign influences and the introduction of new working methods can bring about new kinds of theatre.

The emergence of more than fifty independent companies since the end of the 1980 s has been related either to economic recession or economic boom in Estonia. One of the most recent theatre organizations, the performing arts centre Vaba Lava (Open Space), was created to offer opportunities for Estonian independent companies and freelancers. The advent of Vaba Lava has been a significant phenomenon because the whole concept of work is changing in the twenty-first century. Despite the stability offered by the well-financed repertoire theatre system, more and more performing artists are willing to enjoy more autonomy and flexibility and to work as project-based freelancers. The case study of Vaba Lava describes a theatre organization which is unique in the Estonian theatre field with regard to financing, artistic content, and programming with a focus on social issues such as the problematics of the underprivileged in society and issues of community-building.

We argue that the independent scene in general is more alert to social change and more likely to respond quickly with diverse means of artistic expression to it. With the case study of the new performing arts centre Vaba Lava we will show how an international curated programme has presented themes and forms not previously available in the Estonian theatre. We argue that Vaba Lava could also be an innovative institutional model for the performing arts scene in (Northern) Europe. 


\section{DEVELOPMENT OF THE ESTONIAN THEATRE SYSTEM}

The Estonian theatre system was originally patterned after the nineteenth century model of the German repertory theatre, which usually offered two to three different genres (drama, opera and ballet). Theatres were supported financially by theatre societies, who were responsible for the construction and maintenance of the theatre buildings. It can be said that the foundation for the network of state-subsidized repertory theatres of today was laid down in the second half of the nineteenth century.

However, the Soviet occupation of Estonia in 1940 brought about a transformation of theatre institutions: all theatres in the Soviet Union served as state-subsidised repertory theatres with their own buildings and a permanent troupe with contracts of an indefinite duration. In the 1980s, the Soviet Union faced a deep crisis. When Mikhail Gorbachev became general secretary of the communist party of the Soviet Union in 1985, his program of perestroika ("restructuring") and glasnost ("openness") introduced profound changes in economic practice, international relations as well as in internal affairs. Consequently, social controls imposed by the government eased, citizens were able to express divergent views and the media acquired greater freedom.

In the field of the performing arts, selected theatres in the Soviet Union were granted more freedom and autonomy in making decisions concerning both organisational issues and financial matters (repertoire policy, the number of new productions, realistic ticket pricing, decisions over the size of the company, assignment of awards): the theatres were allowed to earn more of their own income in addition to state funding. ${ }^{1}$ Theatre attendance reached a peak in 1987: all-in-all there were 1.7 million theatre visits, while the population of Estonia is 1.3 million people. ${ }^{2}$

Estonia regained independence in 1991. In terms of the artistic development of the performing arts, this year did not mark any distinct turning point. It is appropriate to talk about a longer period of thorough changes: the end of the 1980s and the first half of the 1990s. Concerning the theatre system: by contrast with the rest of the post-communist countries of Eastern Europe, the former Soviet-era theatre system in Estonia remained intact. For example, no theatre was closed down, the Soviet-era principles of state funding from the late 1980s persisted and the system of appointing artistic and managing directors remained the same.

While in all other spheres of life, especially in culture, ground-breaking reforms took place, which often had a short-term negative effect on the development of the field, the theatre field enjoyed relative stability. One of the reasons why the theatre system was not reformed lay in the fact that theatre has always been the most popular art form in Estonia. According to a survey in $2016,87 \%$ of the inhabitants of Estonia consider theatre as one of the

$1 \quad$ Viller 2004, 69.

2 For a thorough history of Estonian theatre, see Rähesoo 2008, 81-92. 
most important art forms. ${ }^{3}$ During the Soviet period, theatre had actively participated in the independence struggle and for years had been a channel of expressing opposition to Soviet rule.

During this transitional period (the end of the 1980s and the beginning of the 1990s), several important institutional changes took place which strengthened the theatre system. For example, the re-establishment of Cultural Endowment, which in its way is unique to Estonia. The Cultural Endowment is an important vehicle in supporting culture, including theatre. Income of the Endowment is formed from proceeds in the state budget from the excise duty on alcohol and tobacco 3,5\%, and from gambling tax $46 \%{ }^{4}$

When compared to the peak theatre attendance of the late 1980s, when Estonia was still part of the Soviet Union, theatre visits at the beginning of the 1990s plummeted by $50 \%$. By 1992 , the number of theatre visits had fallen to 700,000 . As a result, there were 1 million visits less than before. To compensate for the decline in theatre visits, theatres offered a bigger number of performances, which put pressure on actors who simply had to play more shows. In the 1990s, the financial position of theatres was precarious and with the pressure to earn their own income, the theatres had to meet the expectations of audiences with a taste for lightweight entertainment. ${ }^{5}$

It had become clear that with the normal rehearsal period of several months, the theatres were not able to have a say in active politics such as the independence movement. The theatre of those transitional years turned away from politics to pure art. It discussed eternal themes and mainly staged the classics. Out in the streets big theatrical events were happening (mass demonstrations, song festivals), but the theatre turned out to be rigid and helpless in this situation. The years right after re-independence offered brand new opportunities, most important being the opening of borders to the West. But that liminal period was a period of deep economic crisis. It is important to note that changes in the political situation had left the arts without the role of the opposition that it had enjoyed during the Soviet period. The theatre experienced difficult times in coping with that. After the end of censorship the theatre did not find anything to oppose.

After re-independence, Estonian theatre established new contacts with the performing arts in the West - the theatres started travelling abroad and Western companies came to Estonia with their guest performances. ${ }^{6}$ Those contacts played a significant role for the artistic development of the Estonian performing arts. The calling card of Estonian theatre from the beginning of the 1990s until the mid-2000s was the avant-garde Von Krahl Theatre and, after them, the theatre NO99 (established in 2004). The urge for international contacts was also emphasized by the fact that performing arts festivals start-

\footnotetext{
$3 \quad$ Kivirähk 2016.

$4 \quad$ Estonian Cultural Endowment, 2017.

5 Rähesoo 2008, 81.

6 Saro $2015,95-6$.
} 
ed to flourish - the most important international performing arts festival until now, Baltoscandal, was established in 1990.

If we look at the repertoire of the theatres then until the mid-2010s, the theatre critics were constantly demanding a more socially critical theatre. In the 1990s there were mainly two exceptions: the sociological and documentary theatre of Merle Karusoo ${ }^{7}$ and the critical postdramatic theatre of Von Krahl. The rise of political theatre started in the mid-2010s with the founding of theatre NO99. ${ }^{8}$

What most affected both the institutional and artistic landscape of the Estonian theatre was the founding of independent companies. Already in the mid-eighties, when the rigid Soviet system began to slacken, the first independent theatre companies started to emerge in Estonia. The independent companies of the late 1980s and 1990s were born on the basis of alternative theatre schools and not on the basis of the Estonian Academy of Music and Theatre. Artistically they were focused on alternative, interdisciplinary, more intellectual, experimental theatre as opposed to the mainstream offered by the large institutional theatres.

The emergence of independent theatre companies falls into three distinct groups, while their formation paradoxically coincides with both the time of economic boom (2000-2005) and recession (the 1990s and 2008-2010) in Estonia. The three waves of establishing independent companies were:

- 1987-1996:

VAT Theatre, Von Krahl Theatre, Fine 5 Dance Theatre, etc.

- 2000-2005:

R.A.A.A.M, Kanuti Gildi SAAL, Independent Dance Company STÜ, etc.

- 2008-2010:

Improtheatre, Cabaret Rhizome, Vaba Lava / Open Space, etc.

The new theatres were rather experimental and unconventional both in their working methods and their artistic aims. In the beginning of the 1990s, they seemed to be left somewhat on the edge of the theatre field. However, it was clear that the independent theatres had changed the Estonian performing arts field for good when professional actors were hired by the Von Krahl Theatre in 1998 and when the independent theatres started to win Annual Theatre Awards from the end of the 1990s.

Artistically, the performing arts field in Estonia has clearly changed towards a multiplicity of institutional forms, working methods, performative styles, and genres. A distinct change appeared when a multiplicity of contemporary dance forms started to develop in Estonia from the beginning of the 1990s. In the 1990s only a tiny part of the audience noticed and appreciated that, but it is clear that by the new millennium the contemporary dance field had strongly affected the mainstream. By the 2000s, contemporary dance

$7 \quad$ For more about Merle Karusoo, see Kruuspere 2009, 89-97.

8 For more about NO99, see Linder 2013, 84-96. 
had found its partners also in technological theatre and multimedia theatre. New working methods had been introduced: participatory theatre, immersive theatre, devising theatre, and applied theatre.

As of 2017 the Estonian theatre landscape looks as follows: there are eight state foundations (eight repertory theatres with their own buildings), two municipal theatres, and the National Opera, whose activities are regulated by a separate National Opera Act. In addition, there are more than fifty independent companies and private theatres, with only a few having their own buildings. ${ }^{9}$

The financing of the performing arts institutions is conducted as follows. The state supports the theatres in spite of their form of ownership and it is allocated in the form of activity support, ${ }^{10}$ project-based support, and investment support. ${ }^{11}$ The activity and financing of theatres are regulated by the Performing Arts Institutions Act ${ }^{12}$ and by the National Opera Act. ${ }^{13}$ State subsidies account for the major share of the activity supports of most of the state foundations (the eight large repertoire theatres) covering at present approximately $60-70 \%$ of the current expenditure by these theatres. The two municipal theatres receive subsidies both from the budgets of the state and from local municipalities.

Only fifteen out of more than fifty independent companies receive support directly from the state budget, which covers, on average, 10-40\% of their expenditures. Consequently, most of the independent companies apply for support from the Cultural Endowment of Estonia. Furthermore, independent companies are only entitled to activities support: they do not get support to cover administrative costs. As a result, independent companies are under huge pressure to earn their own income and they are constantly finding other means to fund their artistic projects.

Theatre statistics in recent years show that state support to independent companies and private theatres has been, on average, $5 \%$ of the total support allocated for the performing arts. ${ }^{14}$ Regardless of poor financing opportunities, according to the recent statistics of the Estonian Theatre Agency, independent companies present more than $50 \%$ of all premieres, give over $40 \%$ of all performances and receive $26 \%$ of all theatre visits. In 2016 there were 1,186,008 theatre visits in Estonia. ${ }^{15}$ In addition, more than $40 \%$ of the nominations of the Annual Theatre Awards in all categories announced by the Estonian Theatre Union went to independent companies. ${ }^{16}$ Taking into

$9 \quad$ For more about the theatre system, see Toome 2015, 21-8.

10 Activity support covers both personnel costs and administrative costs.

11 Estonian Cultural Ministry 2017.

12 Performing Arts Institution Act 2017.

13 National Opera Act 2017.

14 Reidolv 2016, 277-81.

15 Estonian Theatre Agency 2017.

16 Estonian Theatre Union 2017. 
consideration both the artistic quality and the quantitative contribution of independent companies, the system of state funding clearly underestimates the notable contribution of the independent scene in the Estonian theatre landscape.

Upon taking a closer look at the theatre statistics, it becomes clear that neither artistic quality nor quantitative indicators such as the number of theatre visits, new productions, and performances is taken into consideration when allocating state subsidy to theatre institutions. Financing theatre institutions relies heavily on subsidies allocated directly from the state budget, whereas the contribution of local governments, private sector, international funds, etc. is rather small.

To give a comparison concerning the financing of the performing arts, Estonia's neighbouring country Finland differs from Estonia: approximately 1/3 of financial support comes from state allocations, 1/3 from local municipalities and 1/3 from the theatres' own income (for example in 2014, the state subsidy accounted for $36 \%$, local council support for $36 \%$, other support $2 \%$ and their own income amounted to $26 \%$ of the total income of big and medium-sized theatres in Finland). ${ }^{17}$

The funding scheme of the performing arts in Estonia relies heavily on state financing, while resources from local municipalities, sponsorship, and donations are marginal. Therefore, Estonian performing artists as well as umbrella organisations both for artists and employers have been putting pressure on the policy makers for decades to adopt the Finnish principles of financing performing arts (henkilötyövuosi - the full-time equivalent manyear). It has never fully materialised. In the new Performing Arts Institutions Act, the Ministry of Culture has disclaimed those principles.

\section{CASE STUDY: PERFORMING ARTS CENTRE VABA LAVA / OPEN SPACE} Vaba Lava was established in 2010 , during a period of economic recession, with the aim of providing opportunities for both established and emerging independent companies in Estonia. It offers the companies both a space for performing and support services as well as serves as a production centre for experimental and unconventional work. ${ }^{18}$ By that time, the Estonian theatre landscape was fairly established and competition for available resources was high. To create a new performing arts centre was possible only on condition that it offered a completely new model at the organisational, financial and artistic level.

Vaba Lava is the first performing arts centre of its kind in Estonia as the concept of a theatre without a resident company is new in Estonia. Vaba Lava opened its new venue in 2014 and it was the first venue built in Tallinn specifically for theatre for one hundred years. During the first years, Vaba Lava

$17 \quad$ Teatteritilastot Finnish Theatre Statistics 2014, 19.

18 Vaba Lava Profile 2017. 


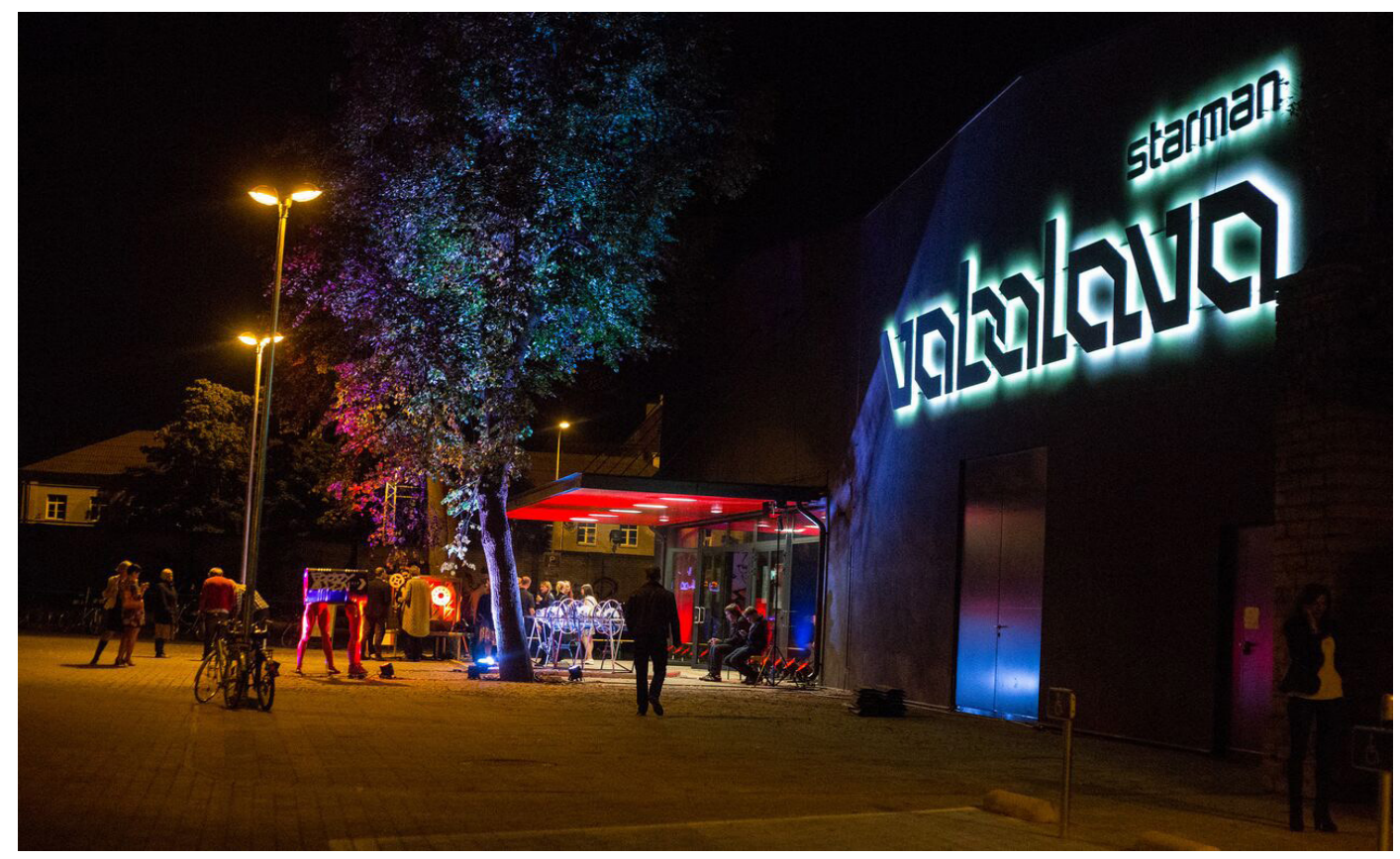

FIGURE 1. Vaba Lava. Photo Aron Urb.

received approximately 60000 visitors. ${ }^{19}$ It presented more than 300 theatre performances and a variety of cultural events. More than fifty-five different local and international companies performed in the Vaba Lava venue per year. In 2018, a second venue is going to be launched in the third-largest town of Narva, a border town with Russia, which historically has been under both Swedish and Russian rule.

Vaba Lava is funded as a public-private partnership and that system is unique in Estonia since public-private partnership is uncommon. It is funded and operated through a partnership of the Estonian Ministry of Culture and private sponsors. ${ }^{20}$ Vaba Lava is a long-term tenant; the Ministry of Culture pays activities support, which is negotiable over the years and covers ca. $70 \%$ of the rent, which is fixed. State support makes up about $40 \%$ of the Vaba Lava budget, which puts pressure on earning its own income. The production costs are financed by the Cultural Endowment and international foundations. Since Vaba Lava prioritizes social topics, integration of different community groups, and educational programmes for freelance performing artists and producers, its activities and programme have been supported from different sources besides the cultural sector (e.g., Ministry of Social Affairs, National Foundation of Civil Society, etc.).

In 2016, financial support from various sources (state funding, grants from the Estonian Cultural Endowment and other local funds) made up 55\% of

$19 \quad$ Eesti Teatri Agentuur 2017.

20 Telecommunications company Starman (since 2018 under the name of Elisa) has a five year sponsorship contract with Vaba Lava. 
the total Vaba Lava budget; grants from international funds made up $10 \%$ of the total, while its own income from ticket sales, renting out the venue for various cultural and commercial events etc. accounted for an additional 35\% of the total budget. The total annual income for Vaba Lava is about 850,000 EUR. Administrative costs made up 35\% of the total costs, personnel costs accounted for $21 \%$. Marketing costs and bringing out the productions of the curated programme accounted for $26 \%$; other costs were $18 \%$ of the total costs. In addition, Vaba Lava organizes and carries out various educational training courses (e.g., a training course for freelance producers of performing arts for organizing international coproductions). ${ }^{21}$

Even if production houses such as Korjaamo Cultural Factory in Helsinki or HAU in Berlin exist in Europe, the Vaba Lava model, with its focus on international curated programmes, is unique in Europe and could serve as a successful model for other international production houses both in Scandinavia and other European countries. The international curated programme enlivens local cultural life and serves as a platform for new means of artistic expression and experimentation.

In 2016, the Estonian Association of Performing Arts Institutions and the Theatre Union jointly carried out a survey on the role of the performing arts in society. ${ }^{22}$ According to the survey, $17 \%$ of theatre-goers in Estonia prioritize innovation in theatre as well as raising issues that are relevant or controversial for society. In addition, from an organisational and administrative point of view, Vaba Lava represents a "flatter", team-oriented, and flexible organizational structure.

The Vaba Lava artistic programme consists of an international curated programme and a side programme of local and international guest performances, concerts, seminars, etc. The system of Vaba Lava's curated programme is also unique in the Estonian and European theatre landscape. Every two years, Vaba Lava has a different team of international curators to draw up a programme from different cultural regions such as German-speaking countries (Germany, Austria, Switzerland), Russia, Francophonie (France, Belgium, Canada), etc. The two (international) curators issue an open call where they state their propositions and the general theme of the season. The season is meant to be an integral whole - this kind of approach has not been practised by other performing arts institutions in Estonia.

In the following we will take a closer look at seasons 2015-2017, when the artistic focus was on German-speaking countries. Season 2015/16, entitled "Common People: More than Naked", asked the artists to redefine, question or challenge the notion of community and collectivity. The emphasis in the programme was on common people, on questioning the identity and everyday life of common people. The themes of the programme covered issues of democracy, mass movement and liberation, self-empowerment of public

$21 \quad$ Teatrielu 2016, 314.

22 Kivirähk 2016. 
spaces, and the social integration of blind people. Heightened focus was placed on the power relationship between male and female genders in society. ${ }^{23}$

Season 2016/17, entitled "In I Out", addressed the notion of integration and adaptation. The themes covered issues of digital identity and the integration of the other. ${ }^{24}$ Furthermore, the season presented sociological and anthropological views on an Estonian identity crisis and tackled the history and future of Estonians and the Russian-speaking minority.

As the focus of the seasons was on socially and politically relevant issues, Vaba Lava also managed to get financial support from outside the cultural sector. The productions of the curated programme helped to raise awareness of socially relevant issues that were also prioritized by the Ministry of Social Affairs: for example, social inequality, gender issues (including gender pay gap) and disabled people. ${ }^{25}$ Financial support was also granted by the two biggest municipalities of Estonia: Tallinn and Tartu.

The two seasons 2015-2017 featured a variety of productions including participatory theatre, dance, documentary theatre, visual theatre, technological theatre, music theatre, and site-specific works in the city space. The programme featured both Estonian and international emerging and established artists of a younger generation who are regularly invited to major festivals in Europe. With the selection of the Estonian artists, the aim of the curators was to encourage the formation of new creative communities rather than presenting existing artistic groups. The selected international artists (Doris Uhlich, Christophe Meierhans, Jan Martens, Julian Hetzel, Oleg Soulimenko, Chris Kondek and Christiane Kühl, etc.) introduced unconventional theatre propositions and involved local people or local artists in their works. The coproductions with international directors were supported by the Austrian Embassy, the Federal Foundation of Austria, INTPA International Net for Dance and Performance Austria, Goethe Institute, Bosch Stiftung, and the Flemish government. It was important that the international projects had the potential to build close links with the public space in Tallinn.

Both seasons featured socially and politically relevant theatre in such a concentration that had never happened before in the Estonian cultural field. One of the aims of the curators was to create controversial debates with their programme which would affect public life in Estonia beyond the theatre. That did happen - the programme got a lot of feedback in the media and the debates not only touched the aesthetic side of a certain performance, but above all the theme or the form that the performance touched upon.

In the following we will pinpoint some unconventional performative strategies from the two seasons of the Vaba Lava curated programme. We will look at four performances that arguably bring something previously unseen

$23 \quad$ Vaba Lava Projects and Vision 2015/16.

24 Ibid.

25 Ministry of Social Affairs. Priorities of 2016. 
into the Estonian theatre. These productions imply strategies of political and applied theatre and we show how theatre can exit from the pure art field and enter the wide field of societal discussions.

In the performance l'd Rather Dance with You (2016), the Vienna-based Russian choreographer and director Oleg Soulimenko together with the Estonian dramaturg Piret Jaaks examined the relationship of two nationalities, Estonians and Russians, today. Estonians and Russians live close together, Russians being the biggest minority of Estonia of about $30 \%$. The performance was based on personal experiences of both Estonian and Russian actors and non-professionals, the common people, on their memories of the past, their imagination, and about their current thoughts on politically relevant issues. The four non-professionals - two Estonians, two Russians were cast through a popular open call. The director's aim was to present people with contrasting backgrounds and opinions. The performance was built up as a TV talk-show. The team devised more than 500 questions and a number of them were presented to the performers during the performance. The performers did not know the questions in advance, so their spontaneous answers and debates where encouraged. The questions were personal (were you mocked at school?), concerning one's everyday life (what are you having for breakfast?), about politics (which party should be in power? do you welcome immigrants in Estonia?), about cultural differences (what are Russian wedding traditions like?), about history (which countries have occupied Estonia?), and about abstract themes (what is the meaning of life?). Part of the audience was sitting on the two sides of the stage and could

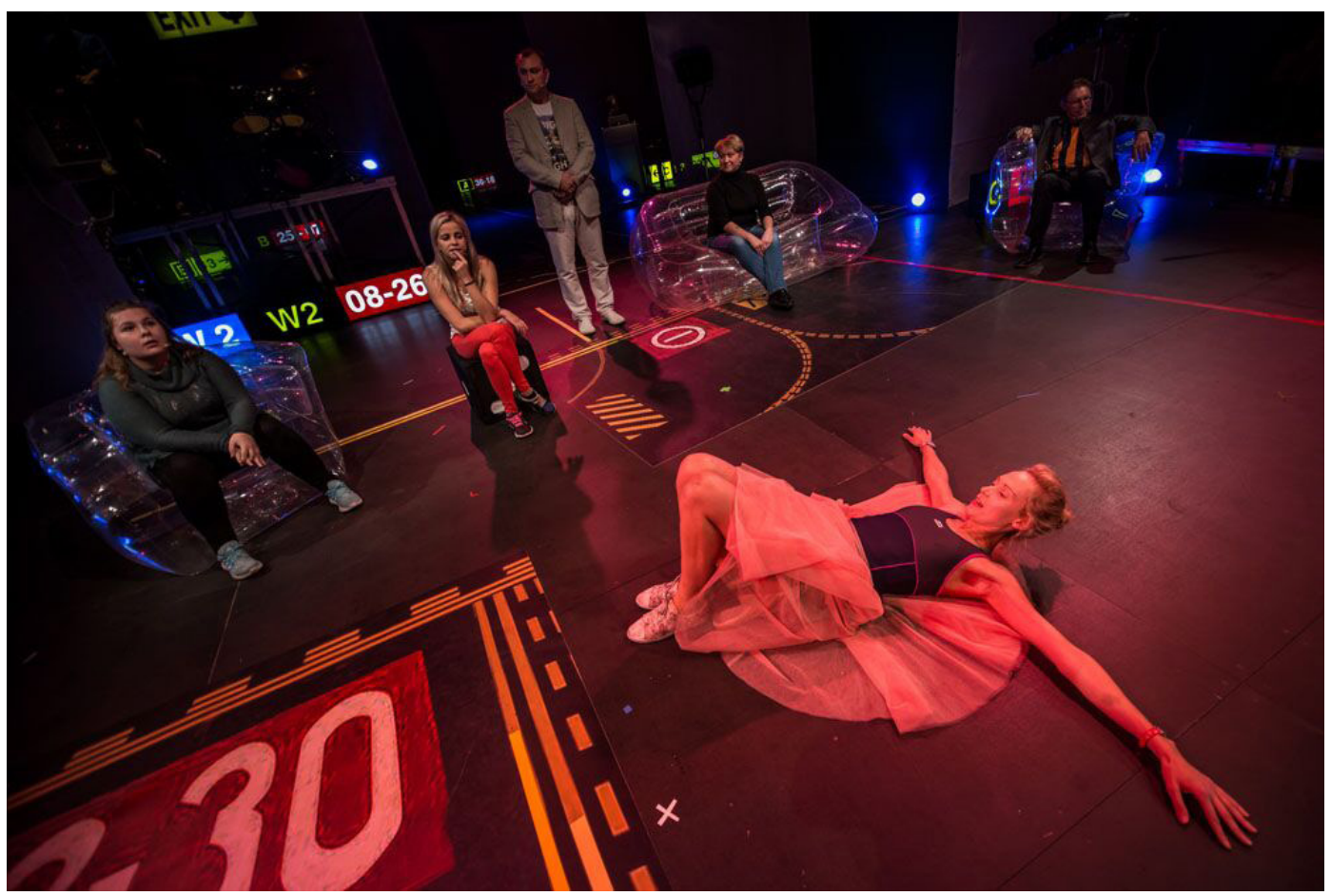

FIGURE 2. I'd Rather Dance with You. Photo Siim Vahur. 
participate in answering some questions. In addition, the performers told an autobiographical story concerning the topic of identity or nationality. The moderators of the whole evening were an Estonian actress Mari-Liis Lill and an Estonian-born Russian actor Nikolai Bentsler. The performance gave an insight into the lives and thoughts of four people. The outcome was a general perspective on history, identity, cultural differences, and the possibilities of accepting the other.

The performance can be seen as political in many aspects. Firstly, it is a hot and relevant topic. Although $30 \%$ of Estonia's population is Russian-speaking, the issues, the views, the problems of this big minority are not really (re) presented in the arts. The performance dealt with the conceptualization of history and today with the relationship between the past and the present. This is considered one of the main functions of political documentary theatre. ${ }^{26}$ The question whether documentary theatre is (or should be) objective and show the topic from different angles has different answers. Peter Weiss, the author of a documentary theatre manifesto from 1968 says that documentary theatre takes sides $^{27}$ and considers the main conflict taking place between the aesthetic and historical truth, i.e. whether to evaluate the aesthetics of a performance or the factual accuracy presented on stage. This was also a discussion point concerning the performance l'd Rather Dance with You.

Secondly, one of the main strategies of producing political theatre is a research-based approach. The director Oleg Soulimenko and the dramaturg Piret Jaaks interviewed dozens of people who had answered the open call and had something to tell about the relationship between Estonians and Russians.

Thirdly, political and documentary theatre often redefines the relationship between the performer and the audience. The audience often has a more participatory function and the performer deals with self-representation. ${ }^{28}$ In letting ordinary people tell their real thoughts on stage, the performance l'd Rather Dance with You touched upon authenticity - a concept very much in discussion in documentary theatre research. One could even talk about a boom of (new) authenticity in the performing arts scene during the last two decades. Closely related to the concept of "authenticity" is the term "egodocument" ${ }^{29}$, which is a personal document, the testimony or recollection of the performer, the expert on stage. That kind of egodocument was used in Oleg Soulimenko's performance, and due to this strategy, different positions and opinions appear and open up a wide discussion for the audience.

The aim of the director, Oleg Soulimenko, was to have as much authenticity on stage as possible, that is to have a "real" talk-show where the moderators-interviewers really don't know where the answers of the guests/perform-

\footnotetext{
$26 \quad$ Martin 2006, 12-13; Paget 2009, 227.

27 Weiss 1998, 247-53.

28 Deck 2011, 18-19.

29 Keim 2010, 127-38.
} 
ers are taking the show. But of course, after playing the performance several times, some themes were the same and the performers wanted to give their favourite answers, or those that got more audience reactions. There is no direct link between authenticity and documentary. Presenting documentary material - egodocuments - on stage gives a feeling of authenticity and sincerity, but presenting fictive material can be authentic as well (in I'd Rather Dance with You one of the professional actors told a "personal" story that turned out to be fictive). So, we can suggest that authenticity is the strategy which affects the audience's response. That is something that the audience is craving for nowadays - the feeling of authenticity - and the theatre makers fulfil that need in creating performances and using certain performative strategies (one of those being documentary).

In order to limit risks, the production was produced by two independent theatres, Vaba Lava and R.A.A.A.M., who both invested in the production. In addition, I'd Rather Dance with You was supported by the Austrian Embassy and the Federal Foundation of Austria. The production got two invitations to festivals: the Estonian Theatre Festival DRAAMA in Tartu and the Estonian theatre showcase festival draamamaa.weekend which is oriented towards international producers and curators.

Another clear red line through the curated programme of Vaba Lava and that again is uncommon in Estonian theatre - is the presentation of the underprivileged on stage. This then, partly, connects to another strategy of political theatre - applied theatre. In 2016 an Estonian director Jaanika Juhanson offered the first professionally produced performance with disabled people in Estonia in the curated programme of Vaba Lava - Who is Afraid of the Blind? There is little awareness of the problems and needs of disabled people in Estonia. The performance was based on surveys, interviews and discussions involving visually impaired people and attempts at raising awareness both about blindness and the visually impaired. The dramaturg of the performance was one of the most successful Estonian playwrights, Martin Algus. He wrote a simple story about young visually impaired people fulfilling their dreams as musicians. But between the dramatic story there were documentary scenes about the real issues concerning the blind.

Who is afraid of the blind? offered the visually impaired and blind people a platform to both voice their issues and display their talents. It was, for the first time in Estonia, that theatre was used as a vehicle to provide education about the issues concerning people with visual impairment. The performance can thus be seen as using the strategies of applied theatre and community theatre.

The general aim of applied theatre is to change something - amongst the participants or in society. The theatre is a tool to turn attention to hidden stories and problems, a tool for social development. Another common aspect is that applied theatre is based on research, is educative or informative, and 


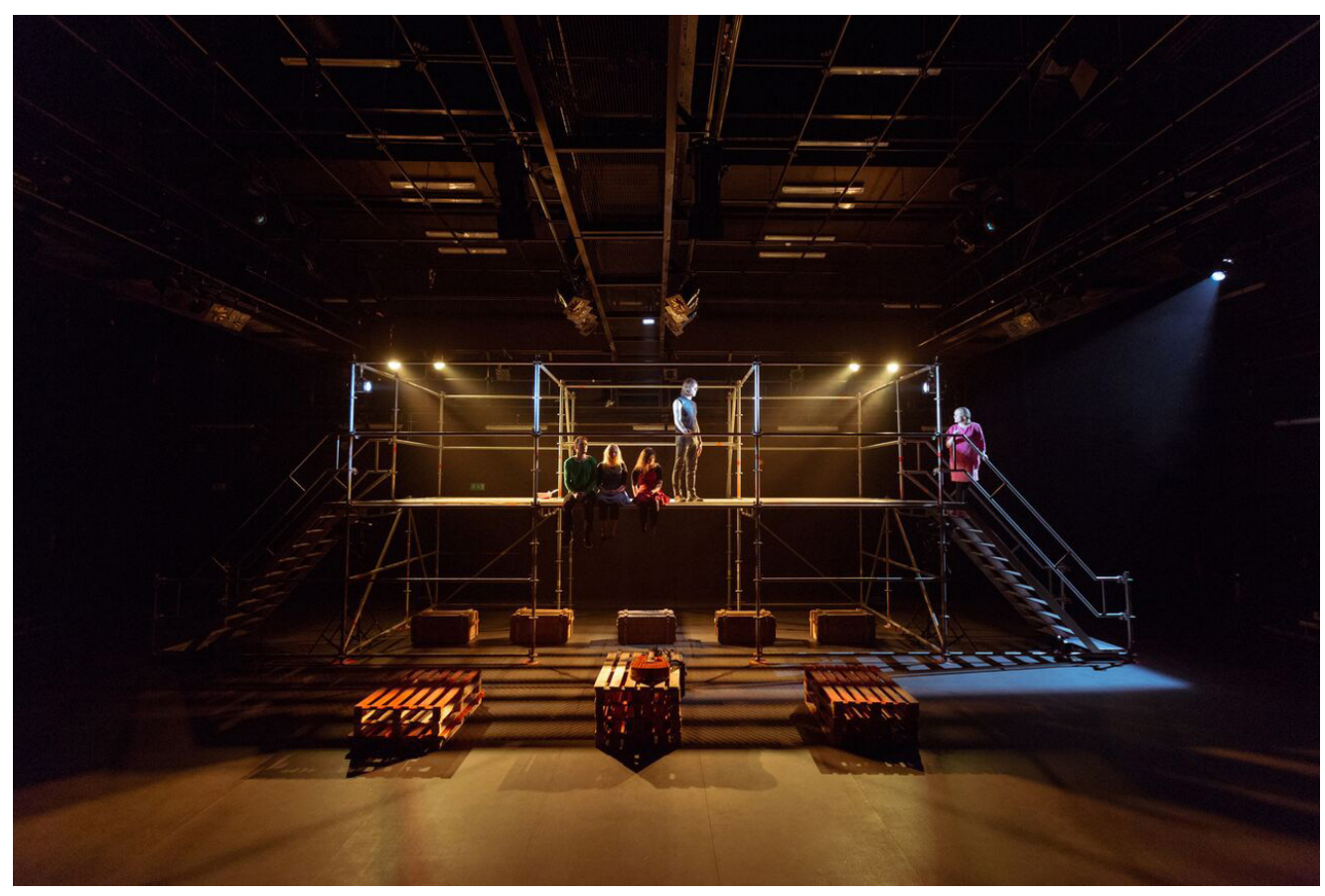

FIGURE 3. Who is Afraid of the Blind? Photo Siim Vahur.

is meant for a community, or takes place with the community. ${ }^{30}$ But what is a community? A community is defined as a dynamic group of people that share common social meanings, but who are constantly interacting with society. ${ }^{31}$

According to Tim Prentki and Sheila Preston, ${ }^{32}$ participation in a community performance can be of a different kind: theatre for the community, theatre with the community, or theatre by the community. Jaanika Juhanson's performance Who is Afraid of the Blind? was theatre with the community. Using the strategy of devising theatre, the community members - the visually impaired people - created ideas and scenes for the performance. It was also theatre by the community (the visually impaired people were actors on stage).

Another defining aspect of a community performance is connected with the notion of periphery, meant both geographically and socially. ${ }^{33}$ Juhanson's performance could be seen as dealing with the social periphery - creating a theatre performance gave a chance to turn attention to the blind community's issues. Another community performance researcher Jan Cohen-Cruz argues similarly: community theatre deals with the non or low represented culture. ${ }^{34}$

In addition to the funding by the Cultural Endowment, the production gained support from the Ministry of Social Affairs as it corresponded with one of the

\footnotetext{
$30 \quad$ Hughes 2011, 186-7.

31 Heddon and Milling 2006, 130-3; Warstat 2009.

32 Prentki and Preston 2009, 19-21.

33 Van Erven 2001, 2.

34 Cohen-Cruz 2006, 432.
} 
priorities of the Ministry of 2016: to support projects that give information and schooling about disabled people and activities that support their independent subsistence in society. The production also got support via the Estonian crowdfunding platform Hooandja.

Finally, we would like to pinpoint another theme that the Vaba Lava curated programme cast light on. The programme highlighted gender issues and the position of women in Estonian society with two performances: Tiina Sööt's documentary and autobiographical performance Real Women, Real Men and Real Others and sex:f (both 2015) conceived and performed by four acclaimed actresses at mainstream theatres: Evelin Võigemast, Mari-Liis Lill, Ursula Ratasepp and Hilje Murel with the help of the dramaturg Maria Lee Liivak.

sex:f presented their playful and feminist work by stating that in our male-dominated world the masculine patterns of life and masculine mindsets
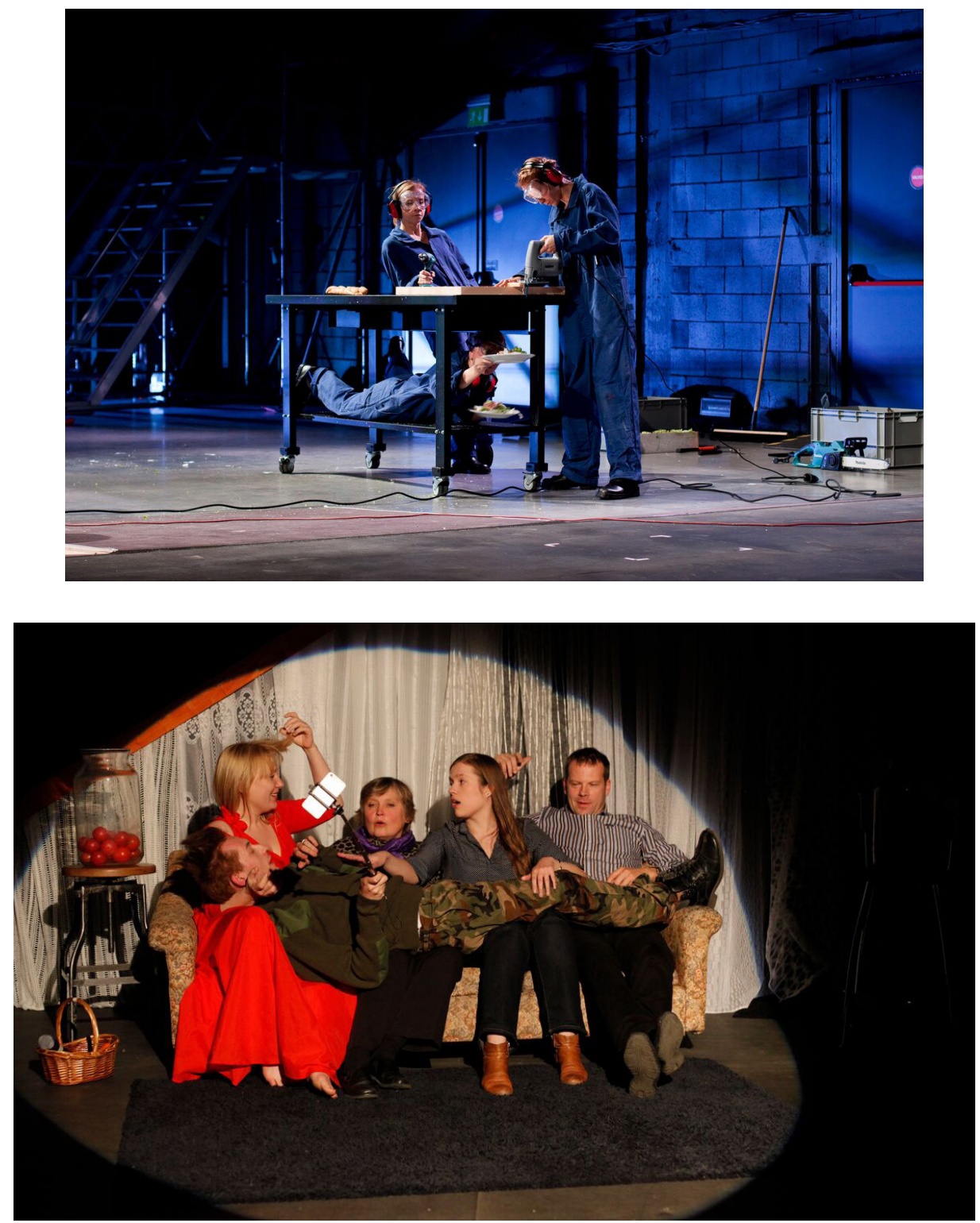

FIGURES 4 and 5. Above: sex:f, below Real Women, Real Men and Real Others. Photo Marianne Karm. 
prevail. The topic indeed is relevant in Estonia which is the country that has the biggest gap in gender-specific income in the whole of the European Union - men in Estonia earn about 30\% more than women when doing equal jobs. ${ }^{35}$ sex:f was a postdramatic performance comprising different scenes addressing the issues from a woman's perspective. They used a documentary approach with the performers providing the audience with facts on the topic of gender inequality. There was also a personal, autobiographical approach with one performer depicting her day as a mother of young children presenting it as if it was a report from the Olympic Games; or in another scene a performer portrayed a victim of domestic violence (also an issue very much discussed in the society at present).

sex:f achieved the most visits in the curated programme, gaining more than half of the visits of the whole curated programme in the season 2015/16. This production was also financially the most successful. At a venue with ordinarily 184 seats, an extra section with 400 seats was built. The performances were sold out and the troupe gave two performances a day to satisfy the demand of the audience. In total, 20 performances of sex:f were given. The production also got support via the Estonian crowdfunding platform Hooandja and it found several sponsors.

sex:f showed one of the strategies of political theatre - devising or collective collaboration - which is also a process not yet very widespread in Estonian theatre. One of the aims of devising is to dissolve hierarchies ${ }^{36}$ and to show multiple views and opinions on the same topic. ${ }^{37}$

Real Women, Real Men and Real Others was conceived and directed by Tiina Sööt, a young performance and visual artist working both in Vienna and Tallinn, and the dramaturg was Aet Kuusik. The performance presented common people from different walks of life - a media researcher, a managing editor of a women's magazine, a drag-queen, an IT person, and a social science school teacher - speaking out and sharing their personal experiences with gender discrimination. Again, the cast was found with an open call and the material was conceived with extensive interviewing. Gender inequality issues were addressed from both an individual and broader social perspective. Real Women, Real Men and Real Others focused on personal stories which were presented on stage using both text and performative tools. The performance showed a documentary and autobiographical approach. Again, the fact that people told their own very personal stories on stage, presented their egodocuments, is uncommon in Estonian theatre. Once again, the two performances on gender issues raised a major discussion in the media about the representation of women, their position in the society and raised awareness of the inadequacy of the binary gender system.

In addition to the funding by the Cultural Endowment, the production was

$35 \quad$ Tackling the gender pay gap in the European Union 2017.

36 Deck 2011, 17-18.

37 Heddon and Milling 2006, 5. 
supported by the Ministry of Social Affairs as it corresponded with two of their priorities of 2016: a) to support activities that minimize the gender pay gap; b) to raise awareness about equal treatment, tolerance and involvement in society. The production also got support from the crowdfunding platform Hooandja. Financial support was also given by the municipal government of Tartu, which meant the production could give guest performances in the second largest town of Estonia. The performance was staged in the small studio hall of Vaba Lava in order to minimize financial risks. It also corresponded artistically: the production had an intimate feel and the closeness of the audience was required.

\section{CONCLUSIONS}

It could be argued that one of the artistic turning points of the performing arts in Estonia is the mid-2000s when the theatre NO99 was established. From that time on, the Estonian theatre started to reach out to the society around it. In the fifteen years before that, the large repertory theatres tried mostly to hold onto their old positions in society and the whole field tried to get accustomed to the new liberal capitalist economy. The outcome by the mainstream was mostly art for art's sake and the theatre had a mainly escapist aim. Mainly due to the political theatre of NO99, theatre reached the front pages of newspapers and other political theatre makers emerged. Another turning point, this time both institutionally and artistically, might be the opening of Vaba Lava in 2014. The new performing arts centre revealed new financing possibilities, new ways of running a venue, new working methods, a stronger urge to work internationally, and a programme that touched upon issues relevant to society.

In looking at the past decades of developments in the field of theatre in Estonia, the most important change, institutionally and aesthetically, is the emergence of multiple forms and the opening up to the outside world. At present, the theatre still enjoys one of the most prominent positions among Estonian cultural habits. Although the position of theatre is indeed strong according to surveys, the field should look to the future and re-consider its financing system. As we have shown, the state financing of theatre institutions is heavily out of balance in favour of large repertory theatres. Alternative sources for theatre financing such as involving local governments, the private sector, and international funds have not been widely considered.

Two reasons could be pointed out as to why private sponsorship of culture is marginal in Estonia. Firstly, the Estonian taxation system does not favour sponsorship (the companies do not get advantages), and secondly, sponsoring culture is not prestigious. As for the private production companies, the market in Estonia is tiny and that is why there exist only a few private commercial production houses. Some of them are focused on mainly Anglo-American comedies and others stage stand-up comedies with well-known actors.

As shown, the support from the Ministry of Culture and by the Cultural Endowment to independent theatres is usually not enough to stage artistically demanding and socially and politically relevant productions. Thus, the 
independent theatres have to be visionary in inventing new ways of creating, producing, and financing a production. As shown with the case of Vaba Lava, independent artists and performing arts institutions have found additional ways of financing. The crowdfunding platform Hooandja is in active use. That is a way to spread ideas and it also contributes to community engagement: the platform connects the artists and the theatre closer to its audience. It helps to select out themes and forms of expression that really touch people.

Financial support could also be found from sources outside the cultural sector: as, for example, the support of the Ministry of Social Affairs for some of the productions of the curated programme of Vaba Lava. It is important to note the symbiosis of the creation process and the financing of a production: the curators and the artists are interested in socially relevant themes and this enables them to apply for innovative kinds of financing, which come from outside the cultural sector. The advent of new kinds of financing possibilities thus help the artists to create productions about socially sensitive issues.

The financial help by local municipalities is far from ideal in Estonia. The local municipalities could develop their role in financing performing arts and their motivation could be to spread theatre to an audience living outside the two major cities and to bring relevant issues and innovative artistic forms to a wider audience.

To conclude, the paper has shown how forming a new institution has helped to develop new forms of performing arts, bringing about new working methods, new financial schemes and new topics and with that, it has evoked discussions about relevant issues in society. 


\section{REFERENCES}

Brandt, Georg W. (ed.)1998. Modern Theories of Drama. A Selection of Writings on Drama and Theatre 1850-1990. Oxford: Clarendon Press

Cohen-Cruz, Jan. 2006. "The Problem Democracy is Supposed to Solve: The Politics of Community based Performance" in The SAGE Handbook of Performance Studies.

Eds. D. Soyini Madison and Judith Hamera. Thousand Oaks: Sage Publications.

Deck, Jan. 2011. "Politisch Theater machen - eine Einleitung" in Politisch Theater machen. Neue Artikulationsformen des Politischen in den darstellenden Künsten. Eds. Jan Deck and Angelika Sieburg. Bielefeld: Transcript.

Deck, Jan and Angelika Sieburg (eds.) 2011. Politisch Theater machen. Neue Artikulationsformen des Politischen in den darstellenden Künsten. Bielefeld: Transcript.

Eesti Teatri Agentuur, http://statistika.teater.ee/stat/main (25 May 2017)

Estonian Cultural Endowment. 2017. http://kulka.ee/about-us/about-endowment (25 May 2017).

Estonian Cultural Ministry. 2017.http://www.kul.ee/en/activities/performing-arts (25 May 2017)

Estonian Theatre Agency. 2017. http://statistika.teater.ee/stat/main (25 May 2017)

Estonian Theatre Union. 2017. http://teatriliit.ee/auhinnad (25 May 2017)

Van Erven, Eugen. 2001. Community Theatre: Global Perspectives. New York: Routledge.

Forsyth, Alison and Chris Megson (eds.) 2009. Get Real. Documentary Theatre Past and Present. New York: Palgrave Macmillan.

Heddon, Deirdre and Jane Milling. 2006 Devising Performance: A Critical History. New York: Palgrave Macmillan.

Hughes, Jenny (with Jenny Kiddi and Catherine McNamara) 2011 "The Usefulness of Mess: Artistry, Improvisation and Decomposition in the Practice of Research in Applied Theatre" in Research Methods in Theatre and Performance. Eds. Baz Kershaw and Helen Nicholson. Edinburgh: Edinburgh University Press.

Keim, Katharina. 2010. "Der Einbruch der Realität ins Spiel" in Reality Strikes Back II. Tod der Repräsentation. Die Zukunft der Vorstellungskraft in einer globalisierten Welt. Eds. Kathrin Tiedemann and Frank M. Raddatz. Berlin: Teater der Zeit, 2010, 127-38.

Kershaw, Baz and Helen Nicholson (eds.) 2011. Research Methods in Theatre and Performance. Edinburgh: Edinburgh University Press.

Kivirähk, Juhan. 2016. Teatri positsioon ja roll ühiskonnas. Tallinn: Turu-Uuringute AS. 
Kreuder, Friedemann \& Michael Bachmann (eds.) 2009. Politik mit dem Körper. Performative Praktiken in Theater, Medien und Alltagskultur seit 1968. Eds. Bielefeld: Transcript.

Kruuspere, Piret, 2009. "Estonian Memory Theatre of the 1990s: Emotional Scale from Fear to Laughter." Nordic Theatre Studies, vol. 21, no.1, 2009, 89-97.

Linder, Eva-Liisa. 2013. "How Theatre Can Develop Democracy: The Case of NO99." Nordic Theatre Studies, vol. 25, no. 1, 2013, 84-96.

Madison, D. Soyini and Judith Hamera (eds.) 2006. The SAGE Handbook of Performance Studies. Thousand Oaks: Sage Publications.

Martin, Carol. 2006. "Bodies of Evidence" in The Drama Review, 50:3, Fall, 2006. DOI https://doi.org/10.1162/dram.2006.50.3.8

Ministry of Social Affairs. 2016. Priorities of 2016, http://www.sotsiaalministeerium.ee/sites/default/files/content-editors/eesmargid ja tegevused/Projektijuhile/Riigieelarvelised toetused/2016.pdf (27 Nov 2017)

National Opera Act. 2017. https://www.riigiteataja.ee/en/eli/520012015010/consolide. (25 May 2017)

Paget, Derek. 2009. "The "Broken Tradition" of Documentary Theatre and Its Continued Powers of Endurance" in Get Real. Documentary Theatre Past and Present. Eds. Alison Forsyth and Chris Megson. New York: Palgrave Macmillan, 224-238.

Performing Arts Institution Act, https://www.riigiteataja.ee/en/eli/512112013014/consolide (May 25 2017)

Prentki, Tim and Sheila Preston. 2009. "Applied Theatre. An Introduction" in The Applied Theatre Reader. Ed. Tim Prentki and Sheila Preston. London and New York: Routledge, 19-21.

Prentki, Tim and Sheila Preston (eds.) 2009. The Applied Theatre Reader. London and New York: Routledge.

Reidolv, Kristiina. 2016. “Otsides teatrivälja tasakaalupunkti” in Teatrielu 2015, Estonian Theatre Union and Estonian Theatre Agency, Tallinn, 2016, 277-81.

Rähesoo, Jaak. 2008. Estonian Theatre. Tallinn: Estonian Theatre Union.

Saro, Anneli. 2015. "Mobility and Theatre: Theatre Makers as Nomadic Subjects." Nordic Theatre Studies, vol. 27, no. 1, 2015, 90-102.

DOI http://dx.doi.org/10.7146/nts.v27i1.24242

Tackling the gender pay gap in the European Union, http://ec.europa.eu/justice/gender-equality/files/gender pay gap/140319 gpg en.pdf (25 May 2017)

Teatrielu 2016. Eesti Teatriliit, Eesti Teatri Agentuur, 2017.

Finnish Theatre Statistics 2014. TINFO - Theatre Info Finland, Helsinki 2015, p. 19. 
Toome, Hedi-Liis. 2015. The functioning of theatre in the city of Tartu: a comparative perspective, University of Tartu Press, 2015.

Vaba Lava Profile, http://vabalava.ee/en/vaba-lava-2/ (25 May 2017)

Vaba Lava Projects and Vision 2015/16,

http://vabalava.ee/en/main-program/curators-20152016/mission-statement/

(25 May 2017)

Warstat, Matthias. 2009. "Gleichheit - Mitwirkung - Teilhabe. Theatrale Gemeinschaftskonzepte vor und nach 1968" in Politik mit dem Körper. Performative Praktiken in Theater, Medien und Alltagskultur seit 1968. Eds. Friedemann Kreuder and Michael Bachmann. Bielefeld: Transcript.

Weiss, Peter. 1998. "The Materials and the Models: Notes Towards a Definition of Documentary Theatre" in Modern Theories of Drama. A Selection of Writings on Drama and Theatre 1850-1990. Ed. Georg W. Brandt. Oxford: Clarendon Press pp. 247-53.

Viller, Jaak. 2004. Teatriorganisatsiooni areng Eestis XX sajandi II poolel. Tartu.

\section{AUTHORS}

Madli Pesti, PhD, theatre researcher and critic. Lecturer and researcher at Tartu University and Estonian Academy of Music and Theatre. 2015-2017 programme curator of Vaba Lava (Open Space).

Kristiina Reidolv, PhD student in theatre research, Tartu University. 2009-2012 Executive Manager of Estonian Association of Performing Arts Institutions (EETEAL). Since 2012 member of the board of Vaba Lava (Open Space). 